\title{
The sign of the Cross of Andreas in the iris and Diabetes Mellitus: a longitudinal study
}

\section{O sinal da Cruz de Andréas na íris e o Diabetes Mellitus: um estudo longitudinal La señal de la Cruz de Andreas en el iris y la Diabetes Mellitus: un estudio longitudinal}

\author{
Léia Fortes Salles ${ }^{1}$, Maria Júlia Paes da Silva ${ }^{2}$
}

${ }^{1}$ Universidade de São Paulo, Escola de Enfermagem, Programa de Pós-Graduação em Enfermagem na Saúde do Adulto, São Paulo, SP, Brazil.

${ }^{2}$ Universidade de São Paulo, Escola de Enfermagem, Departamento de Enfermagem Médico-Cirúrgica, São Paulo, SP, Brazil.

\section{ABSTRACT}

Objective: To compare the development of diabetes mellitus in subjects with and without the sign of the Cross of Andreas in the iris over a period of four years. Method: A prospective, descriptive study of quantitative approach. This cohort study had 91 patients without the disease, with and without the signal. The monitoring was conducted by means of the records in medical charts. Results: At the end of the research, $28.2 \%$ of the group with the sign of the Cross of Andreas was diagnosed with diabetes and $56.5 \%$ had two or more episodes of impaired glucose tolerance. In the group without the sign, $4.4 \%$ was diagnosed with the disease and $24.5 \%$ had two or more episodes of glucose intolerance. There was a statistically significant difference between the groups regarding the development of the disease and glucose intolerance. Conclusion: The group with the Cross of Andreas developed more glucose intolerance and diabetes than the group without the sign.

\section{DESCRIPTORS}

Iridology; Diabetes Mellitus; Complementary Therapies; Integrative Medicine; Disease Prevention; Nursing. 


\section{INTRODUCTION}

Although most techniques used in Integrative and Complementary Practices have arisen in antiquity, they were 'rediscovered' by the Western world only in recent decades, thanks to the movement for change of paradigm in understanding the world. These techniques have purposes of health promotion, prevention and treatment of diseases ${ }^{(1)}$.

The increasing demand for care with these practices is a global fact however, caution is necessary, as well as investment in research and in the formation of well-trained staff. With more discussions and debates about this issue, evidences of safety and effectiveness must be found through research and stronger guidance found in the World Health Organization manual on strategies for the use of traditional medicine ${ }^{(1-2)}$.

Investigations are important not only for health professionals who want to use these practices, but for all who deal with patients and have to guide them through the proper choice of complementary treatments for their problem $^{(3)}$.

This paper investigates the relationship between iridiagnosis and diabetes mellitus.

\section{Diabetes Mellitus}

The growth of chronic diseases such as diabetes mellitus (DM) is in part due to the rapid aging of the world population ${ }^{(4)}$.

$\mathrm{DM}$ is a disease of multiple action, considered one of the major public health problems in the world given its high prevalence and high rate of mortality and morbidity ${ }^{(5)}$.

Type 2 diabetes accounts for over $85 \%$ of diabetes cases and is characterized by two metabolic defects: insulin resistance and low secretion of the hormone. It has genetic component, but is linked to obesity, sedentary lifestyle and environmental factors such as urbanization, industrialization, increased life expectancy and associated diseases such as heart problems, hypertension and increase of cholesterol level ${ }^{(6)}$. The metabolic syndrome (MS) is present in $50 \%$ of patients at the time of DM diagnosis ${ }^{(7)}$.

In 2013, the International Diabetes Federation (IDF) estimated that 386 million people had DM worldwide. Of this total, $80 \%$ lived in poor and developing countries and 175 million were unaware of their condition. The Federation also pointed that in 25 years the number of people affected by the disease will pass to 592 million $^{(8-9)}$.

The prevalence of DM in the countries of Central and South America was estimated at 26.4 million people and projected to 40 million in 2030. According to these projections, in the year 2030, Brazil will move from 8th to 6th position, with prevalence of $4.6 \%$ and $11.3 \%$, respectively ${ }^{(7)}$.

International studies suggest that the cost of care related to diabetes is about two to three times higher than costs of care provided to non-diabetic patients and is directly related to the occurrence of chronic complications ${ }^{(7)}$.

\section{IRIDOLOGY AND IRIDIAGNOSIS}

Iridology means the study of the iris and Iridiagnosis is a science that allows identifying physical, emotional and mental aspects of individuals by their iris ${ }^{(10)}$. In this study, the term used to designate iridiagnosis is Iridology, because it is a more familiar term and used in the literature.

Iridology is a propaedeutic method that allows knowing the weakened organs in the body and their evolutionary stages at any given time. The purpose of this method is to detect evolving disturbances and intervene early to prevent illnesses ${ }^{(10)}$.

The iris is a microsystem fully formed at six years of age that contains information on the individual. Professionals who use Iridology can carry out a prophylactic and therapeutic approach through pre-diagnosis ${ }^{(10-11)}$.

Iridology does not diagnoses, but only indicates the shock organs of the body and thus, the predisposition to sickness. In no occasion Iridology replaces complementary tests ${ }^{(10)}$.

Based on the grounds of Iridology, the iris is an extension of the brain, richly endowed with nerve endings, tiny blood capillaries and other types of specialized tissues. It is connected with all organs and tissues of the body, via optical thalamus and nervous system, and reveals conditions of the most remote areas of the body through changes in the stroma and the iris fibers ${ }^{(11)}$.

According to Iridology professionals, the Sign of the Pancreas and the Cross of Andreas are two signs in the iris suggestive of predisposition for diabetes ${ }^{(10-11)}$.

The Sign of the Pancreas indicates that the pancreas is a shock organ, i.e., an organ born weakened in the body, and exposed to noxious stimuli, may have illnesses. By identifying the pancreas as a shock organ, we can only say this is a weaker organ with predisposition to fall ill. One can not ascertain whether the disease which may develop will be pancreatitis, tumors or diabetes. However, among all the pancreas diseases, diabetes mellitus is the one of highest frequency. In the condensed map of Iridology (Figure 1) ${ }^{(10)}$, the pancreas is located in the right iris at seven (comparing the iris to a clock). The signs showing decrease in tissue density, such as fiber apertures, indicate the organ weakness.

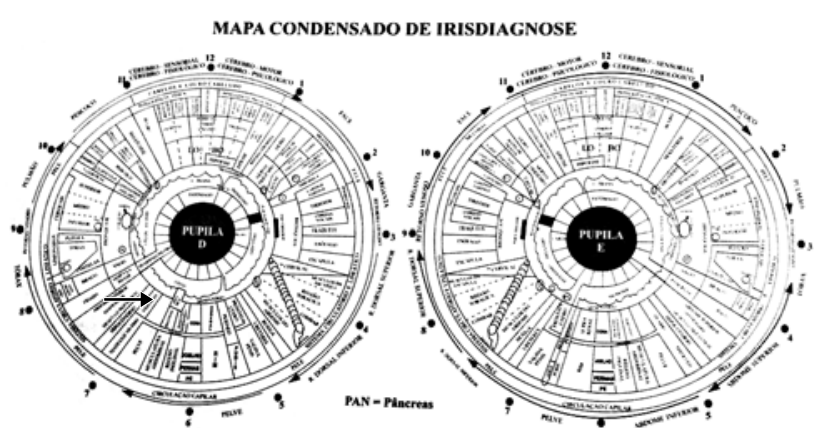

Figure 1 - Condensed map of Iridology and Sign of the Pancreas. Source: Battello CF. Iridologia e irisdiagnose: o que os olhos podem revelar (Iridology and iridiagnosis: what the eyes can reveal - still not published in English). Ground; 2009 ${ }^{(10)}$.

The other sign is the Cross of Andreas (Figure 2) ${ }^{(12)}$, studied by German Iridology that refers to this sign as specifically indicative of predisposition to diabetes mellitus. The Cross of Andreas, can be viewed in both eyes in the form of four gaps (fiber openings) located at 10, 20, 40 and 50 minutes, comparing the iris with the clock. These gaps also mean less dense and weak tissues, predisposed to illness. 

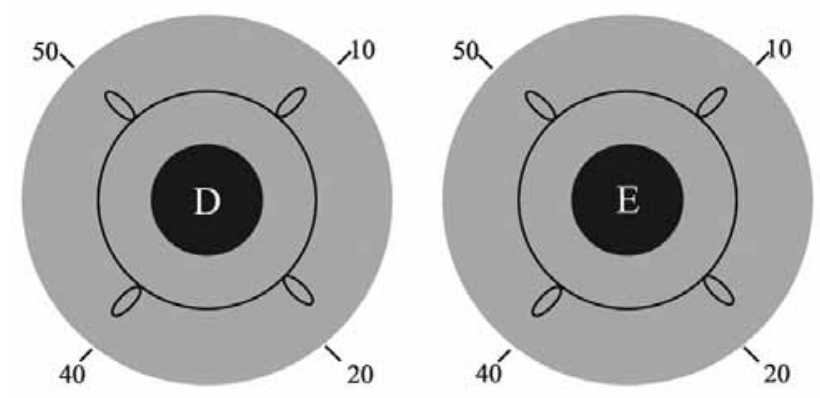

Figure 2 - Cross of Andreas.

Source: Battello CF. Iridologia total (Total iridology - still not published in English). São Paulo: Ground; $1996^{(12)}$.

A study with 97 individuals with DM aged over 30 years aimed to determine the prevalence of iridologic signs such as the Sign of the Pancreas and the Cross of Andreas. After their iris analysis, it was found that the adjusted prevalence of the Sign of the Pancreas and the Cross of Andreas were respectively $98 \%$ and $89 \%$. There were significant associations $(\mathrm{p}<0.001)$ among the three risk factors for diabetes (obesity, sedentary lifestyle and heredity) with both studied signs ${ }^{(13)}$.

Subsequently, another study was carried out aiming to determine the prevalence of these signs in individuals with and without diabetes and its heritability. Data collection took place between 2010 and 2011, and 410 individuals aged over 30 years participated. People with diabetes had a higher prevalence of the studied iridologic signs. The Student's $t$ test revealed a statistically significant difference in the prevalence of these signs among patients with and without diabetes, and in those with and without family history of the disease. The chi-square test showed that having both signs increases the chance of developing diabetes and only the Sign of the Pancreas alone is not sufficient to develop the disease ${ }^{(14)}$.

Considering the lack of studies in the area and the fact that this is an innovative subject, the examination board during the defense of the cited thesis ${ }^{(14)}$ recommended that the specific sign for DM - the Cross of Andreas - should be followed by a longer period in a longitudinal study.

The main objective of this study was to compare during a four-year period, the development of diabetes mellitus and impaired glucose tolerance in individuals without the disease, and with and without the Cross of Andreas sign in the iris, through the monitoring of medical charts of individuals without diabetes who were part of the doctoral thesis database, collected in $2010^{(14)}$.

The hypothesis was that individuals with the sign of the Cross of Andreas in the iris will develop the disease more frequently.

\section{METHOD}

\section{TYPE OF STUDY}

A prospective, descriptive study of quantitative approach.

\section{StUdY LOCATION}

The study was carried out at the Teaching Health Center Geraldo de Paula Souza of the Public Health School, University of São Paulo.

\section{SAMPLE}

The sample was taken from part of a doctoral research database collected in 2010, consisting of 215 individuals without diabetes.

Based on a population of 215 individuals, a significance level of 0.05 and $85 \%$ confidence interval, the suggested sample size was 90 people. For possible losses, $20 \%$ was added to this number therefore, the sample comprised 108 volunteers divided into two groups: 54 individuals with the Cross of Andreas and 54 without the sign in the iris.

The inclusion criteria were the following: being enrolled and in treatment at the Teaching Health Center Geraldo de Paula Souza; adults aged over 40 years; and knowledge about family history of DM. This last item is justified by the fact that one of the specific objectives was to correlate the studied iris sign with family history of the disease. The exclusion criteria were presence of prosthetic eye, scar and pterygium covering more than two quadrants of the iris in both eyes and difficulty with keeping the eyes open.

\section{DATA COLLECTION PROCEDURES}

The study was submitted to the Plataforma Brasil (Brazilian government electronic system for approval of studies involving human beings) and approved by the CEP (Ethics Committee) of the School of Nursing, University of São Paulo (under number CAAE 05654712.4.0000.5392).

The database used in this study was collected in 2010. The study period was between October 2012 and August 2014.

In our initial proposal, individuals without diabetes would be separated into two groups, with and without the sign of the Cross of Andreas in the iris, and each group would be randomized. The first 54 individuals of each group who agreed to participate would be included in the study.

The first step was to remove all individuals aged under 40 years of the previous database. In total 50 patients were withdrawn, leaving 165 people in the database.

Then a search was made in the files of the institution to check the situation of each patient in the database in relation to the continuity of care.

In the first search, it was found that 45 individuals had their medical records placed in the archive by medical discharge, transfer or death, remaining only 120 individuals. On this occasion, it was also reported by the Nursing and the administration employees that many other patients with irregular address information would be transferred to service units nearby their homes.

Given this situation, randomization was not possible. As there was no return from many patients of the previous database in the first two months of research, we chose to include new patients to the study until completing 108 individuals. In the end, the initial sample of the present study 
was formed by $76 \%$ of individuals from the previous database and $24 \%$ of new participants who did not have diabetes either, and had been treated in the institution since 2010.

This was a convenience sampling. It included the first 54 individuals of each group. All patients were informed about the study and agreed to participate by signing the Informed Consent.

Data collection was performed at four different times every five months. The first one was held on the day of acceptance to participate, through an interview to fill out the form of medical records, check the patient's medical records and photograph the iris. For every search in the medical records, notes were taken about data of the last consultation: medical diagnoses, test results of blood glucose and/ or glycosylated hemoglobin, total cholesterol and fractions, as well as blood pressure.

\section{DATA PROCESSING}

Data were processed by number and percentage, the statistical test used was the Pearson's chi-squared test.

\section{RESULTS}

The study started with 108 volunteers in total, but only 91 reached the end of the investigation. The reasons for data loss were: transfer of patients to an institution closer to their residence $(35.3 \%)$, no return for the medical appointment (47\%) and lack of recent exam (17.7\%).

The sample comprised $76.9 \%$ of women and $23.1 \%$ of men aged between 42 and 79 years, a mean age of 61.5 years.

The group without the sign of the Cross of Andreas consisted of 46 people. The mean age was 60.2 years and $82.2 \%$ had no family history of DM. More than half (51.2\%) of the sample presented the Sign of the Pancreas in the iris. Although this sign is not specific to DM, it can contribute to the disease development, since its presence indicates the pancreas is a shock organ and likely to sicken ${ }^{(10-11)}$.

In the group with the sign of the Cross of Andreas, formed by 45 people, the average age was 63 years and $84.8 \%$ had a family history of diabetes. All individuals presented the sign of the Cross of Andreas, and the Sign of the Pancreas also appeared in $100 \%$ of the sample.

Table 1 - Sample characterization of both groups - São Paulo, SP, Brazil, 2014.

\begin{tabular}{lcc}
\hline & $\begin{array}{c}\text { With Cross of } \\
\text { Andreas }\end{array}$ & $\begin{array}{c}\text { Without Cross } \\
\text { of Andreas }\end{array}$ \\
\hline $\mathrm{N}$ & 45 & 46 \\
Mean age & 63 years & 60 years \\
$\begin{array}{l}\text { Family history of DM } \\
\begin{array}{l}\text { Presence of the Sign of the } \\
\text { Pancreas }\end{array}\end{array}$ & $84 \%$ & $17.8 \%$ \\
\hline
\end{tabular}

Most patients (76\%) were from the doctoral research database and at that time all belonged to the group without diabetes (2010). In the first stage, we found that among the 45 individuals without the disease and with the sign, seven had already developed DM. In the group without the sign, no patient had developed the disease.

At the end of the investigation, 13 individuals (28.2\%) of the group with the sign were diagnosed with diabetes mellitus, $13(28.2 \%)$ with metabolic syndrome and 26 (56.5\%) patients had two or more episodes of glucose intolerance, demonstrated by laboratory tests.

In the group without the sign, at the end of the study, two patients (4.4\%) were diagnosed with DM, three (6.7\%) with metabolic syndrome and $11(24.5 \%)$ had two or more episodes of glucose intolerance.

Table 2 - Comparison of the prevalence of diabetes, glucose intolerance and metabolic syndrome between groups at the end of four years - São Paulo, SP, Brazil, 2014.

\begin{tabular}{lcccc}
\hline & \multicolumn{2}{c}{$\begin{array}{c}\text { With Cross of } \\
\text { Andreas }\end{array}$} & \multicolumn{2}{c}{$\begin{array}{c}\text { Without Cross of } \\
\text { Andreas }\end{array}$} \\
\hline Diabetes & 13 & $28.2 \%$ & 2 & $4.4 \%$ \\
Glucose intolerance & 26 & $56.5 \%$ & 11 & $24.5 \%$ \\
Metabolic syndrome & 13 & $28.2 \%$ & 3 & $6.7 \%$ \\
\hline
\end{tabular}

The Pearson's chi-squared statistical test showed that the differences between groups regarding the development of diabetes, $(p=0,002)$, glucose intolerance $(p=0,004)$ and metabolic syndrome $(\mathrm{p}=0,007)$ were statistically significant.

The sign of the Cross of Andreas had statistically significant association with family history of diabetes $(\mathrm{p}<0.001)$.

\section{DISCUSSION}

As already explained in the introduction, the scholars of Iridology and Iridiagnosis affirm the Sign of the Pancreas and the Cross of Andreas are two iridologic signs that suggest a predisposition to diabetes mellitus ${ }^{(10-11)}$. The sign of the Cross of Andreas is specific for diabetes, but the Sign of the Pancreas is not. The latter only suggests the pancreas is a shock organ that can sicken in harmful conditions such as unhealthy lifestyle habits ${ }^{(10-11)}$.

In this study, in the group without diabetes and with the sign of the Cross of Andreas, all individuals also had the Sign of the Pancreas. In this group, throughout four years, $28.2 \%$ developed diabetes and $56.5 \%$ glucose intolerance, which shows the synergy of these two signs.

In the group without diabetes and without the Cross of Andreas, 51.2\% of individuals presented the Sign of the Pancreas. At the end of the study, some participants also developed a disease: $4.4 \%$ had DM and $24.5 \%$ had glucose intolerance. One of the people who developed DM and $54.5 \%$ of individuals who had glucose intolerance showed the Sign of the Pancreas in the iris. Therefore, it is noteworthy that although a person does not have the specific sign for DM (Cross of Andreas) and neither family history of the disease, if the pancreas is a shock organ and the life habits are inadequate, the disease may appear.

The importance of iridology in showing the predisposition to a disease precociously is strengthened by the new sciences in development, such as epigenetics and nutrigenomics, which study how the change in lifestyle and 
eating habits can change the gene expression and regulate biological processes ${ }^{(15)}$. A study carried out at the University of California shows that changes in lifestyle are capable of causing genetic changes in three months, generating greater genetic stability ${ }^{(16)}$.

The statistical tests showed the difference between groups was statistically significant in the development of diabetes, glucose intolerance and metabolic syndrome ( $\mathrm{p}=$ 0.002, 0.004 and 0.007, respectively), confirming the observation of iridologists and previous studies of the authors of this research ${ }^{(10-14)}$.

At the end of the study, the group with the sign of the Cross of Andreas had more cases of metabolic syndrome (MS), which is statistically significant compared to the group without the sign $(\mathrm{p}=0.007)$. However, given the results of cholesterol and blood pressure exams, more people could be diagnosed with MS in both groups. As the doctor did not make the diagnosis, even though the individual presented exams and blood pressure measurement compatible with the syndrome, the individual was not considered as having the problem. Therefore, although the results show correlation between the sign of the Cross of Andreas and MS, new studies are needed to clarify this item.

There was a statistically significant correlation between the Cross of Andreas and family history of diabetes, confirming the results of previous studies ${ }^{(13-14)}$.

An important fact is that individuals who developed diabetes and had prescription of medications and diets still presented high levels of blood sugar (in their majority). This reinforces the situation found in a previous study $^{(14)}$ and that it is necessary to do something differ- ent, because medication prescriptions and the guidance on diets solely are not enough. Moreover, this challenge can be extended to populations without the disease, where risk factors for diabetes and related diseases are prevalent, although modifiable, increasing the number of candidates to this pathology $y^{(17)}$.

In four years, $28.2 \%$ of the volunteers in the group with the Cross of Andreas, developed DM and more than half had two or more episodes of glucose intolerance. This seems a small time compared with the amount of people who increased the statistics of the disease prevalence. More studies are needed to clarify many other issues. Can the inappropriate lifestyle alone determine the development of DM in people with predisposition? How long does it take until a predisposition becomes a disease and which factors contribute to it? Is it possible to avoid that a predisposition becomes a disease?

The Iridology proposal of detecting the predisposition to DM precociously looks very interesting for allowing the start of adjustments in eating behavior and in relation to physical activity at a young age, facilitating the maintenance of proper habits to prevent the development of disease and its severe complications.

\section{CONCLUSION}

At the end of four years, the group of volunteers with the sign of the Cross of Andreas in the iris developed more diabetes $(p=0.002)$, glucose intolerance $(p=0.004)$ and metabolic syndrome $(p=0.007)$ than the group of volunteers without the sign. The Cross of Andreas, indicates predisposition to diabetes.

\section{RESUMO}

Objetivo: Deste trabalho foi comparar o desenvolvimento do Diabetes Mellitus em indivíduos com e sem o sinal da Cruz de Andréas na íris em um período de quatro anos. Método: Estudo prospectivo, descritivo e com abordagem quantitativa. Participaram deste estudo de coorte 91 pacientes sem a doença, com e sem o sinal na íris. $\mathrm{O}$ acompanhamento foi realizado por meio dos registros nos prontuários. Resultados: Ao final da investigação, 28,2\% do grupo com o sinal da Cruz de Andréas foi diagnosticado com Diabetes e 56,5\% apresentou dois ou mais episódios de intolerância à glicose. No grupo sem o sinal, 4,4\% foi diagnosticado com a doença e $24,5 \%$ teve dois ou mais episódios de intolerância à glicose. Houve diferença estatisticamente significativa entre os grupos quanto ao desenvolvimento da doença $(\mathrm{p}=0,002)$ e intolerância à glicose $(\mathrm{p}=0,004)$. Conclusão: $\mathrm{O}$ grupo com a Cruz de Andréas desenvolveu mais intolerância à glicose e diabetes que o grupo sem este sinal na íris.

\section{DESCRITORES}

Iridologia; Diabetes Mellitus; Terapias Complementares; Medicina Integrativa; Prevenção de Doenças; Enfermagem.

\section{RESUMEN}

Objetivo: El objetivo de este trabajo fue comparar el desarrollo de la Diabetes Mellitus en individuos con y sin la señal de la cruz de Andreas en el iris en un período de cuatro años. Método: Estudio prospectivo, descriptivo y con abordaje cuantitativo. Participaron de este estudio de cohorte 91 pacientes sin la enfermedad, con y sin la señal en el iris. El seguimiento fue llevado a cabo mediante registros en las fichas. Resultados: Al final de la investigación, el 28,2\% del grupo con la señal de la cruz de Andreas fue diagnosticado con Diabetes y el 56,5\% presentó dos o más episodios de intolerancia a la glucosa. En el grupo sin la señal, el 4,4\% fue diagnosticado con la enfermedad y el $24,5 \%$ tuvo dos o más episodios de intolerancia a la glucosa. Hubo diferencia estadísticamente significativa entre los grupos en cuanto al desarrollo de la enfermedad $(\mathrm{p}=0,002)$ e intolerancia a la glucosa $(\mathrm{p}=0,004)$. Conclusión: El grupo con la cruz de Andreas desarrolló más intolerancia a la glucosa y diabetes que el grupo sin esta señal en el iris.

\section{DESCRIPTORES}

Iridología; Diabetes Mellitus; Terapias Complementarias; Medicina Integral; Prevención de Enfermedades; Enfermería. 


\section{REFERENCES}

1. Salles LF, Silva MJP. Enfermagem e as práticas complementares em saúde. São Caetano do Sul: Yendis; 2011.

2. World Health Organization (WHO). WHO traditional medicine strategy 2014-2023. Geneva; 2013.

3. Christensen MC, Barros N F. Complementary and alternative medicine in medical teaching: systematic review. Rev Bras Edu Med. 2010;34(1):97-105.

4. Goulart FAA. Doenças crônicas não transmissíveis: estratégias de controle e desafios para os Sistemas de Saúde. Brasilia: Ministério da Saúde; Organização Pan-Americana da Saúde; 2011.

5. World Health Organization (WHO). Diabetes [Internet]. Geneva: WHO; 2015 [cited 2015 Apr 13]. Available from: http://www.who.int/ mediacentre/factsheets/fs312/en/

6. American Diabetes Association. Diagnosis and classification of diabetes mellitus. Diabetes Care. 2014;37Suppl 1:S81-90.

7. Brasil. Ministério da Saúde; Secretaria de Atenção à Saúde, Departamento de Atenção Básica. Estratégias para o cuidado da pessoa com doença crônica : diabetes mellitus. Brasília; 2013. (Cadernos de Atenção Básica, n. 3).

8. Mora-Morales E. Estado actual de la diabetes mellitus en el mundo [editorial]. Acta Med Costarri. 2014;5 (2):44-46.

9. International Diabetes Federation. Epidemiology and prevention [Internet]. Brussels, Belgium; 2014 [cited 2015 Apr 13]. Available from: http://www.idf.org/epidemiology-prevention

10. Batello CF. Iridologia e irisdiagnose: o que os olhos podem revelar. $3^{\text {a }}$ ed. São Paulo: Ground; 2009.

11. Kalsa GS. Iridologia integrada: a ciência e a arte da revelação do holograma humano. São Paulo: Mandras; 2009.

12. Battello CF. Iridiologia total. São Paulo: Ground; 1996.

13. Salles LF, Silva MJP, Araújo EAP. The prevalence of iridiologic signs in individuals with Diabetes Mellitus". Acta Paul Enferm. 2008;21(3):474-9.

14. Salles LS, Silva MJP, Battello CF. Avaliação do risco para diabetes pela análise da íris: uma possibilidade. Cad Naturol Terap Complem. 2013;2(3):21-7.

15. Deus KJ, Conceição RS. Diabetes mellitus tipo 2: a relação genética-nutrientes. Nutrire. 2012;37(2):199-214.

16. Dod HS, Bhardwaj R, Sajja V, Weidner G, Hobbs GR, Konat GW, et al. Effect of intensive lifestyle changes on endothelial function and on inflammatory markers of atherosclerosis. Am J Cardiol. 2010;105(3):362-7.

17. Lima ACS, Araújo MF, Freitas RW, Zanetti ML, Almeida PC, Damasceno MM. Risk factors for type 2 Diabetes Mellitus in college students: association with sociodemographic variables. Rev Latino Am Enfermagem. 2014;22(3):484-90.

Financial Support: National Council for Scientific and Technological

Development - CNPq Process number 163000/2013-1 